\begin{tabular}{cc}
\hline Jurnal Pendidikan Biologi 8 (1) (2018) $31-38$ \\
Jurnal Pendidikan Biologi \\
2
\end{tabular}

\title{
Analisis Keterampilan Psikomotorik Mahasiswa Pada Praktikum Biokimia dan Korelasinya dengan Hasil Belajar Kognitif
}

\author{
Etika Dyah Puspitasari ${ }^{1, *}$, Novi Febrianti ${ }^{2}$ \\ 1,2 Pendidikan Biologi, Fakultas Keguruan dan Ilmu Pendidikan, Universitas Ahmad Dahlan, Kampus 4, \\ Jl. Ringroad Selatan, Tamanan, Banguntapan, Bantul, 55191, Daerah Istimewa Yogyakarta, Indonesia
}

\section{INFO ARTIKEL}

Histori Artikel

Received 13 Desember 2018

Revised 24 Desember 2018

Accepted 29 Desember 2018

Published 4 Januari 2019

\section{Keywords:}

Correlation,

Psychomotor,

Cognitive Achivement,

Biochemistry Practice

\begin{abstract}
Biochemistry practice is a basic practicum that must be mastered by biology education students. Skills in biochemistry practicums are the basis used in practicum physiology, genetics, microbiology, and other materials in biology. This study aims to analyze psychomotor skills achieved by students in biochemical practicums and examine the relationship between cognitive learning outcomes and psychomotor learning outcomes of biology education students in biochemical practicums, especially in the experimental material for making solutions and measuring $\mathrm{pH}$. This research is a quantitative descriptive study with a sample of 40 biology education students. Learning outcomes data were analyzed using quantitative and qualitative analysis, and the correlation between psychomotor and cognitive learning outcomes was analyzed using Pearson Correlation analysis at $\alpha=0.01$. The results showed that psychomotor skills that were mastered by students in biochemistry practicum (making solutions and $\mathrm{pH}$ measurements) included levels 1-4, with an achievement percentage of $89.19 \%$ at level perception; $97.30 \%$ at the level set; $51.62 \%$ at the guided response level and $72.97 \%$ at the mechanism level, with psychomotor learning outcomes averaging 58 (sufficient category). The cognitive value of students in the experimental for making solutions and $\mathrm{pH}$ measurements was 63.32 (good category). There is a positive correlation between psychomotor and cognitive learning outcomes of students in biochemistry practicum $(r=0.67)$ with a strong correlation category.
\end{abstract}

Copyright (C) 2018 Universitas Negeri Medan. Artikel Open Access dibawah lisensi CC-BY-4.0 (https://creativecommons.org/licenses/by/4.0)

\section{How to Cite}

Puspitasari, E. D. \& Febrianti, N. (2018) Analisis Keterampilan Psikomotorik Mahasiswa Pada Praktikum Biokimia dan Korelasinya dengan Hasil Belajar Kognitif. Jurnal Pendidikan Biologi, 8(1), 31-38.

\section{PENDAHULUAN}

Praktikum merupakan bagian integral dari kegiatan belajar dan mengajar Biologi. Kegiatan praktikum berperan dalam mencapai tujuan pendidikan biologi. Menurut Rustaman
(2003), terdapat empat alasan pentingnya praktikum yaitu praktikum dapat membangkitkan motivasi belajar, dapat mengembangkan keterampilan dasar melakukan eksperimen, menjadi wahana belajar pendekatan ilmiah dan menunjang pemahaman materi pelajaran. 
Begitu pula menurut Suryaningsih (2017) bahwa dengan praktikum, maka pembelajar diberikan kesempatan untuk dapat membuktikan teori, menemukan teori maupun mengelusidasi teori.

Praktikum biologi merupakan suatu proses pembelajaran biologi yang dapat dijadikan sarana oleh siswa untuk dapat mengaitkan kemampuan kognitifnya dan kempuannya dalam melakukan eksperimen di dalam laboratorium (Hindriana, 2016). Pentingnya kegiatan praktikum dalam menunjang proses belajar dan pembelajaran untuk mencapai tujuan belajar pendidikan biologi juga perlu diimbangi dengan proses penilaian kegiatan praktikum yang tepat. Apabila kegiatan praktikum sudah dilaksanakan dengan baik namun tidak diimbangi dengan proses penilaian yang baik, maka hasil belajar mahasiswa tidak dapat tercermin dengan baik, sehingga hasil penilaian menjadi bias. Tentunya hal tersebut menjadi tidak baik bagi proses pembelajaran mahasiswa, karena proses penilaian pada pembelajaran dapat berfungsi sebagai assessment for learning dan assessment as learning.

Assessment for learning berarti penilaian dapat digunakan untuk pembelajaran, yaitu hasil dari penilaian dapat dimanfaatkan oleh pendidik yaitu dosen untuk mengevaluasi proses pembelajarannya dan melakukan tindak lanjut terhadap hasil belajar mahasiswa. Wijayanti \& Mundilarto (2015) menyebutkan bahwa hasil penilaian dapat berfungsi sebagai umpan balik baik bagi pendidik maupun peserta didik, sehingga dapat digunakan untuk memantau proses pembelajaran, kemajuan belajar dan prestasi belajar.

Biokimia merupakan salah satu mata kuliah dasar pada Program Studi Pendidikan Biologi maupun Biologi, karena materi biokimia menjadi dasar dalam mempelajari materi biologi yang lebih lanjut baik itu fisiologi, genetika, mikrobiologi dan lainnya. Materi biokimia menjadi sangat penting untuk dapat dikuasai oleh mahasiswa biologi maupun pendidikan biologi. Selain teori biokimia, kegiatan praktikum biokimia juga merupakan hal yang penting. Praktikum biokimia biasanya merupakan praktikum awal yang diajarkan kepada mahasiswa yang menjadi dasar praktikum sebelum kegiatan praktikum biologi yang lain. Pada praktikum biokimia mahasiswa akan diajarkan mengenai percoba-an ketepatan dan ketelitian menggunakan alat, keterampilan membuat larutan dan melakukan uji suatu bahan. Keterampilan dalam praktikum biokimia tersebut sangat penting untuk dikuasai oleh mahasiswa karena keterampilan tersebut akan terus digunakan dalam kegiatan praktikum pada materi biologi yang lebih lanjut. Keterampilan psikomotorik dalam praktikum dapat dibedakan menjadi enam level, yaitu perception, set, guided response, mechanism, complex overt response, adaption dan origination (Kasilingam \& Chinnavan, 2014; Hamid et al., 2012).

Keterampilan mahasiswa dalam pelaksanaan praktikum biokimia menjadi sesuatu hal yang penting. Keterampilan dalam praktikum merupa-kan keterampilan yang harus dikuasai karena merupakan suatu kebutuhan abad 21 . Keterampilan mahasiswa dalam menggunakan dan merangkai alat di laboratorium merupakan keterampilan yang harus dikuasai sebagai bagian dari keterampilan inkuiri (Osman et al., 2013; Hiong \& Osman, 2013). Selaian itu kegiatan praktikum akan berpengaruh terhadap penguasaan materi mahasiswa dalam teori biokimia. Murti et al. (2014), menyatakan bahwa kegiatan praktikum dapat meningkatkan hasil kognitif mahasiswa dalam materi anatomi tumbuhan. Hal tersebut juga sejalan dengan penelitian Destalia et al. (2014), bahwa dengan praktikum dapat meningkatkan hasil belajar dan pemecahan masalah. Oleh 
karena itu tidak hanya kemampuan kognitif yang harus dikuasai oleh mahasiswa namun juga keterampilannya dalam kegiatan praktikum harus dikuasai. Berdasarkan penelitian Maknun et al. (2012), rata-rata tingkat keterampilan esensial lab mahasiswa calon guru biologi memiliki keterampilan 35,50\%, sedangkan kompetensi motorik labnya sebesar $59,6 \%$. Berdasarkan hasil penelitian tersebut diketahui bahwa keterampilan esensial laboratorium dan keterampilan motorik laboratorium mahasiswa masih kurang, namun penelitian tersebut terbatas pada praktikum ekologi.

Penelitian terkait penilaian psikomotorik praktikum biokimia belum banyak dilakukan, apalagi untuk mengetahui adanya korelasi antara kemampuan kognitif dan psikomotorik mahasiswa pada praktikum biokimia. Padahal kompetensi mahasiswa dalam laboratorium tidak sama dengan kemampuan kognitifnya dalam mengerjakan soal tes (Ferris \& Aziz, 2005). Oleh karena itu penelitian ini bertujuan untuk mengkaji keterampilan psikomotorik yang dikuasai mahasiswa pendidikan biologi pada praktikum biokimia serta mempelajari adanya korelasi antara keterampilan psikomotorik mahasiswa dengan kemampuan kognitifnya pada praktikum biokimia khususnya pada materi percobaan pembuatan larutan dan pengukuran $\mathrm{pH}$.

\section{METODE}

Penelitian ini merupakan penelitian korelasional yang bertujuan untuk mengetahui hubungan serta tingkat hubungan antara hasil belajar psikomotorik dan hasil belajar kognitif mahasiswa dalam praktikum biokimia. Pada penelitian ini juga mendeskripsikan hasil data kuantitatif yang diperoleh.

Populasi pada penelitian ini adalah mahasiswa Pendidikan Biologi Fakultas Keguruan dan Ilmu Pendidikan Universitas
Ahmad Dahlan. Mahasiswa yang dipilih merupakan mahasiswa semester dua dan sedang menempuh matakuliah praktikum biokimia dan mengikuti praktikum biokimia materi percobaan pembuatan larutan dan pengukuran $\mathrm{pH}$. Total jumlah mahasiswa sebanyak 88 orang mahasiswa (6 golongan). Penentuan sampel pada penelitian ini dilakukan dengan teknik purposive sampling dan diambil sebanyak 40 orang mahasiswa (3 golongan).

\section{Instrumen Penelitian}

Instrumen yang digunakan dalam penelitian ini menggunakan instrumen penilaian psikomotorik berupa angket yang terdiri dari 80 item pernyataan yang digunakan untuk menilai keterampilan mahasiswa selama proses praktikum hingga pengumpulan hasil laporan praktikum. Intrumen penilaian psikomotorik yang digunakan telah divalidasi, terdiri dari level 1-4 keterampilan psikomotorik (perception, set, guided response dan mechanism). Instrumen tersebut terdiri dari 80 item pernyataan yang digunakan untuk mengukur keterampilan mahasiswa. Pada level perception terdiri dari 3 item pernyataan, level set terdiri dari 2 pernyataan, level guided response terdiri dari 60 item pernyataan dan level mechanism terdiri dari 15 item pernyataan. Penilaian keterampilan psikomotorik mahasiswa dilakukan oleh asisten praktikum biokimia menggunakan instrumen penilaian psikomotorik. Instrumen penilaian kemampuan kognitif yang digunakan berupa soal essay sebanyak 5 soal dan diberikan kepada mahasiswa sebelum mahasiswa melakukan kegiatan praktikum. Level soal kognitif yang digunakan meliputi level C1-C4.

\section{Analisis Data}

Teknik analisis data yang digunakan dalam penelitian ini adalah analisis deskriptif kuantitatif. Analisis validitas butir instrumen 
penilaian psikomotorik menggunakan Exploratory factor analisys (EFA). Terdapat empat indikator yang perlu diperhatikan dalam teknik EFA yaitu Kaiser-Meyer-Olkin Measure of sampling adequacy (KMO, MSA), Barteltt's test of sphericiti, anti-image correlation, dan muatan faktor (factor loading). Sebagi kriteria umum apabila tingkat Bartelltt's test of sphericity $\mathrm{p}<$ 0,5 , nilai KMO-MSA $>0,5$ dan nilai antiimage correlation $>0,5$ menunjukkan bahwa data sampel layak dianalisis. Hasil analisis validitas butir menggunakan Exploratory factor analysis (EFA) disajikan pada Tabel 1.

Tabel 1. Hasil Uji Validitas Intrumen

\begin{tabular}{cccc}
\hline Komponen & KMO-MSA & BTS & Keterangan \\
\hline Perception & 0,820 & 0,00 & Valid \\
Set & 0,849 & 0,00 & Valid \\
Guided respons & 0,901 & 0,00 & Valid \\
Mechanism & 0,862 & 0,00 & Valid \\
\hline
\end{tabular}

Nilai kognitif mahasiswa dihitung dengan rentang nilai 0-100. Nilai psikomotorik mahasiswa diperoleh dari konversi skor yang diperoleh mahasiswa menjadi nilai dengan rentang 0-100. Data kuantitatif skor penilaian keterampilan psikomotorik mahasiswa yang telah diubah menjadi nilai skala 100 dianalisis dan ditentukan kriterianya ke dalam lima kriteria panafsiran hasil pengukuran disajikan pada Tabel 2.

Tabel 2. Kategorisasi Nilai Keterampilan Psikomotorik dan Kognitif Mahasiswa

\begin{tabular}{ccc}
\hline No & Rentang Nilai & Interpretasi \\
\hline 1 & $81-100$ & Sangat Baik \\
2 & $61-80$ & Baik \\
3 & $41-60$ & Cukup \\
4 & $21-40$ & Kurang \\
5 & $<20$ & Sangat Kurang \\
\hline
\end{tabular}

Selanjutnya data nilai psikomotorik dan kognitif dianalisis korelasinya. Uji korelasi antara hasil belajar psikomotorik dan hasil belajar kognitif menggunakan uji Pearson Correlation dianalisis dengan bantuan program
SPSS versi $20 \alpha=1 \%$. Interpretasi pada uji korelasi dilakukan untuk pengambilan keputusan statistik dan untuk melihat arah hubungan korelasi. Interpretasi untuk pengambilan keputusan dapat dilakukan dengan melihat nilai signifikansi pada tabel analisis korelasi dengan SPSS yaitu jika nilai signifikansi > 0,01 , maka tidak ada korelasi yang signifikan. Pada uji korelasi terdapat rentang koefisien korelasi (r) antara 0-1 yang menunjukkan semakin besar nilai korelasi (mendekati angka satu) maka semakin besar korelasinya dan sebaliknya (Tabel 3).

Tabel 3. Kriteria koefisien korelasi

\begin{tabular}{cc}
\hline Koefisien Korelasi (r) & Kriteria korelasi \\
\hline $0,000-0,199$ & Sangat lemah \\
$0,200-0,399$ & Lemah \\
$0,400-0,599$ & Cukup \\
$0,600-0,799$ & Kuat \\
$0,800-1,00$ & Sangat Kuat \\
\hline
\end{tabular}

\section{HASIL DAN PEMBAHASAN}

\section{Hasil Ketercapaian Keterampilan Psikomotorik}

Berdasarkan hasil analisis data dapat diketahui persentase ketercapaian keterampilan psikomotorik mahasiswa masing-masing level psikomotorik, disajikan pada Tabel 4.

Tabel 4. Persentase ketercapaian level psikomotorik mahasiswa

\begin{tabular}{cc}
\hline Level psikomotorik & Persentase (\%) \\
\hline Perception & 89,19 \\
Set & 97,30 \\
Guided response & 51,62 \\
Mechanism & 72,97 \\
\hline
\end{tabular}

Berdasarkan hasil pada Tebel 4, dapat diketahui bahwa 89,19\% mahasiswa mampu menguasai semua item penilaian psikomotorik pada level 1 (perception), pada level dua (set) hampir seluruh mahasiswa dapat menguasai keterampilan psikomotorik tersebut yaitu sebesar 97,30\%. Pada level guided response 
hanya $51,62 \%$ keterampilan yang dilaksanakan oleh mahasiswa, dan pada level mechanism sebesar $72,97 \%$ yang dikuasai oleh mahasiswa.

\section{Hasil Belajar Psikomotorik dan Kognitif}

Berdasarkan hasil analisis data diperoleh hasil rata-rata nilai keterampilan psikomotorik mahasiswa 58. Nilai tersebut masuk dalam kategori cukup. Hasil analisis data nilai psikomotorik dan kognitif mahasiswa disajikan pada Tabel 5.
Tabel 5. Hasil belajar psikomotorik dan kognitif

\begin{tabular}{lcc}
\hline Hasil Belajar & Nilai rata-rata & Kategori \\
\hline Psikomotorik & 58 & Cukup \\
Kognitif & 64 & Baik \\
\hline
\end{tabular}

Korelasi Hasil Belajar Psikomotorik dan Kognitif

Analisis korelasi hasil belajar kognitif dan psikomotorik dilakukan menggunakan uji Pearson Correlation pada $\alpha=1 \%$. Hasil analisis menunjukkan bahwa koefisien korelasi antara hasil belajar psikomotorik dan kognitif mencapai 0,674 masuk dalam kriteria korelasi kuat. Hasil tersebut disajikan pada Tabel 6.

Table 6. Hasil analisis korelasi nilai psikomotorik dan nilai kognitif mahasiswa

\begin{tabular}{lccc}
\hline Korelasi & Signifikansi & Korelasi (r) & Keterangan \\
\hline Nilai Psikomotorik dan Nilai Kognitif & 0.00 & 0,67 & $\begin{array}{c}\text { Korelasi kuat } \\
(\mathrm{r}=0,600-0,799)\end{array}$ \\
\hline
\end{tabular}

\section{Pembahasan}

Keterampilan psikomotorik mahasiswa yang dinilai pada penelitian ini hanya 4 level keterampilan psikomotorik awal, yaitu level 1 (perception), level 2 (set), level 3 (guided response) dan level 4 (mechanism). Keempat level psikomotorik tersebut dipilih karena praktikum biokimia merupakan praktikum wajib bagi semester 2 dan merupakan praktikum awal di Program studi Pendidikan Biologi, sehingga mahasiswa masih banyak dibimbing oleh asisten praktikum. Berdasarkan hasil data dan analisis penguasaan keterampilan psikomotorik mahasiswa pada praktikum biokimia hampir semua mahasiswa dapat menguasai level satu psikomotorik yaitu perception (mencapai 89,19\%) kategori sangat baik. Hal tersebut menunjukkan bahwa mahasiswa sebelum melakukan kegiatan praktikum sudah dapat terampil memilih alat dan bahan yang akan digunakan selama praktikum, selain itu mahasiswa juga sudah mampu merumuskan tujuan praktikum pada laporan hasil praktikum.
Pada level dua psikomotorik yaitu set, keterampilan mahasiswa mencapai 97,30\%. Level set merupakan kesiapan mahasiswa sebelum melakukan kegiatan praktikum maupun sebelum membuat laporan hasil praktikum. Pada penelitian ini keterampilan set diamati pada kesiapan mahasiswa telah menuliskan urutan cara kerja praktikum biokimia yang akan dilakukan, sebelum memulai praktikum, serta menuliskan setiap data hasil pengamatan yang diperoleh selama praktikum. Hasil analisis menunjukkan bahwa 97,30\% mahasiswa menguasai level set, hasil tersebut masuk kategori sangat baik.

Pada level guided response, mahasiswa melakukan kegiatan praktikum mengikuti instruksi dari asisten atau mengikuti langkah kerja sesuai buku petunjuk praktikum. Oleh karena itu pada level ketiga yaitu guided response terdiri dari item penilaian yang paling banyak dalam penilaian yaitu mencapai 50 item pernyataan penilaian dari 80 item pernyataan. Pada level tersebut pada aspek pelaksanaan praktikum terdiri dari keterampilan membuat larutan $\mathrm{HCl}$ dengan berbagai 
konsentrasi, membuat larutan $\mathrm{NaOH} 2 \%$, membuat larutan $\mathrm{CH}_{3} \mathrm{COONa} 0,2 \mathrm{M}$ sebanyak $100 \mathrm{ml}$, membuat larutan gelatin $1 \%$ sebanyak $100 \mathrm{ml}$, membuat larutan $\mathrm{NaH}_{2} \mathrm{PO}_{4} \mathrm{H}_{2} \mathrm{O} 0,2 \mathrm{M}$ pH 5 sebanyak $100 \mathrm{ml}$ dan pada aspek penyusunan laporan praktikum terdiri dari keterampilan membandingkan hasil pengamatan dengan teori, menyusun pembahasan hasil, membuat kesimpulan praktikum dan menyusun laporan praktikum. Pada level ini mahasiswa hanya menguasai $51,62 \%$ dari total item keterampilan dan masuk dalam kategori cukup. Rendahnya level guided response ini dikarenakan adanya pembagian tugas dalam pelaksanaan kegiatan praktikum, sehingga tidak semua materi percobaan dilakukan oleh setiap mahasiswa. Oleh karena itu penguasaan keterampilan guided response hanya berkisar separuh dari total penilaian. Hal ini juga dapat digunakan sebagai saran perbaikan kegiatan praktikum agar setiap acara percobaan dapat dipraktekkan oleh mahasiswa, sehingga keterampilan mahasiswa dapat menguasai setiap keterampilan praktikum yang dilaksanakan.

Pada level ke 4 yaitu mechanism, level tersebut merupakan level tertinggi yang digunakan dalam menilai kegiatan praktikum biokimia dalam penelitian ini. Level mechanism menunjukkan keterampilan mahasiswa yang dilakukan secara mandiri dalam waktu singkat dan sudah menjadi kebiasaan (Hamid et al., 2012), pada level ini mahasiswa dapat melakukan kegiatan praktikum dengan benar tanpa harus dibimbing maupun mengikuti petunjuk praktikum. Indikator pada level mechanism ini antara lain menghitung volume larutan, menimbang bahan, menentukan batas tinggi atau volume suatu larutan pada alat ukur (labu ukur, pipet ukur dan gelas ukur), memanaskan gelatin, serta melakukan pengukuran $\mathrm{pH}$. Pada level tersebut mahasiswa mampu menguasai dengan baik, hal ini ditunjukkan dari hasil analsis bahwa mahasiswa menguasai $72,97 \%$ dari total item level mechanism yang harus dilakukan. Berdasarkan hasil analisis data, terdapat keterampilan level mechanism yang tidak dikuasai mahasiswa misalnya pada pengukuran volume larutan, mahasiswa sering tidak memperhatikan batas miniskus larutan, selain itu keterampilan melarutkan gelatin dengan cara pemanasan, masih terdapat mahasiswa yang tidak mengaduk larutan gelatin.

Berdasarkan hasil analisis keseluruhan keterampilan psikomotorik yang dilakukan oleh mahasiswa, rata-rata mendapatkan nilai 58. Nilai tersebut masuk dalam kategori cukup. Nilai yang masih belum baik tersebut dipengaruhi oleh adanya pembagian tugas dalam pelaksanaan praktikum, sehingga sebagian keterampilan level guided response tidak dilakukan oleh setiap mahasiswa, sehingga nilai mahasiswa menjadi cukup rendah. Hal ini juga sesuai dengan hasil penelitian Maknun et al. (2012), bahwa keterampilan laboratorium mahasiswa calon guru biologi masih rendah pada praktikum ekologi. Rendahnya keterampilan psikomotorik maupun keterampilan laboratorium selain karena adanya pembagian kerja mahasiswa dalam kelompok praktikum juga dapat disebabkan karena selama ini perhatian penilaian pada praktikum masih dipusatkan pada penilaian ranah kognitif, sehingga ranah psikomotorik belum diperhatikan secara sungguh-sungguh.

Hasil penilaian kognitif pada penelitian ini diperoleh dari hasil pretest. Penilaian kognitif biasanya merupakan pusat dari hasil pembelajaran (Kasilingam \& Chinnavan, 2014). Berdasarkan hasil analisis data, nilai kognitif rata-rata pretest mahasiswa sebesar 63,32, masuk kategori baik. Hal tersebut menunjukkan bahwa mahasiswa yang mengikuti praktikum biokimia memiliki pengetahuan awal dalam melaksanakan praktikum sebesar 63,32\%. Hasil tersebut masuk dalam kategori baik, namun masih 
sangat perlu ditingkatkan. Adanya pengetahuan yang baik sebelum melaksanakan suatu kegiatan praktikum diharapkan dapat membantu mahasiswa dalam melaksanakan proses praktikum dengan lebih baik. Berdasarkan hasil analisis korelasi antara hasil penilaian psikomotorik mahasiswa dan hasil penilaian kognitif pada Tabel 6, dapat diketahui bahwa nilai signifikansi $<0,01$. Hal tersebut menunjukkan bahwa terdapat korelasi antara hasil penilaian psikomotorik dan kognitif pada mahasiswa. Hasil koefisien korelasi mencapai $\mathrm{r}=0,67$ menunjukkan bahwa korelasi anatara penilaian psikomotorik dan kognitif mahasiswa pada praktikum biokimia terdapat korelasi yang kuat dan positif, yaitu semakin tinggi nilai kognitif mahasiswa maka nilai psikomotoriknya juga semakin tinggi. Sönmez, (2017), menyatakan bahwa hasil belajar kognitif akan berkorelasi dengan kemampuan psikomotoriknya, selain itu mahasiswa yang mendapatkan hasil belajar tinggi juga memiliki karakter afektif yang baik. Hal tersebut juga selaras dengan penelitian Rosa (2015) dan (Sutrisno et al., 2007), bahwa terdapat kaitan antara kemampuan siswa pada ranah kognitif dan psikomotorik. Pembelajaran dengan metode eksperimen dapat meningkatkan hasil belajar kognitif dan keterampilan proses sains. (Subekti \& Ariswan, 2016). Oleh karena itu terdapat korelasi yang kuat antara hasil belajar psikomotorik dan kognitif. Hasil analisis korelasi yang kuat menunjukkan bahwa mahasiswa yang memiliki pengetahuan yang baik sebelum melaksanakan praktikum dapat lebih siap dalam melaksanakan kegiatan praktikum, sehingga dalam proses praktikum lebih dapat menunjukkan keterampilannya dalam menggunakan alat dan bahan, maupun melakukan percobaan. Hasil tersebut dapat didukung dengan hasil analisis pada keterampilan level 1 dan 2 yaitu perception dan set, bahwa mahasiswa dapat menguasai dengan cukup baik.
Hasil belajar psikomotorik mahasiswa dalam praktikum biokimia juga dipengaruhi oleh kemampuan kognitifnya, begitupula dengan kemampuan kognitif mahasiswa dapat dipengaruhi oleh keterampilan psikomotoriknya selama proses pembelajaran praktikum. Oleh karena itu dalam proses pembelajaran biologi termasuk pembelajaran biokimia perlu diperhatikan aspek kemampuan kognitif dan psikomotoriknya karena antara hasil belajar kognitif dan psikomotorik dapat saling berkorelasi.

\section{KESIMPULAN}

Berdasarkan hasil penelitian dan analisis data dapat disimpulkan bahwa ketercapaian keterampilan psikomotorik mahasiswa pendidikan biologi pada praktikum biokimia mencapai $89,19 \%$ pada level perception, $97,30 \%$ pada level set, 51,62\% pada level guided response dan $72,97 \%$ pada level mechanism. Hasil belajar keterampilan psikomotorik rata-rata mencapai nilai 58 pada kategori cukup, sedangkan nilai kognitif rata-rata mencapai 63,32 masuk dalam katagori baik. Terdapat korelasi positif antara hasil belajar psikomotorik dan kognitif mahasiswa pada praktikum biokimia dengan nilai $r=0,67$ dengan kategori korelasi kuat.

\section{DAFTAR PUSTAKA}

Destalia, L., Suratno, \& Aprilya, S. (2014). Peningkatan Keterampilan Pemecahan Masalah dan Hasil Belajar Melalui Penerapan Pembelajaran Berbasis Masalah (PBM) dengan Metode Eksperimen pada Materi Pencemaran Lingkungan. Pancaran, 3(4), 213-224.

Ferris, T. L. J., \& Aziz, S. M. (2005). A Psychomotor Skills Extension to Bloom's Taxonomy of Education Objectives for Engineering Education School of Electrical and Information Engineering, University of South Australia. Exploring Innovation in Education \& Research in Taiwan., (March), 1-5.

Hamid, R., Baharom, S., Hamzah, N., 
Badaruzzaman, W. H. W., Rahmat, R. A. O. K., \& Raihan Taha, M. (2012). Assessment of Psychomotor Domain in Materials Technology Laboratory Work. Procedia - Social and Behavioral Sciences, 56 (Ictlhe), 718-723. https://doi.org/10.1016/j.sbspro.2012.09.708

Hindriana, A. F. (2016). The Development of Biology Practicum Learning based on Vee Diagram for Reducing Student Cognitive Load. Journal of Education, Teaching and Learning, 1(2), 61-65.

Hiong, L. C., \& Osman, K. (2013). A conceptual framework for the integration of $21^{\text {st }}$ century skills in biology education. Research Journal of Applied Sciences, Engineering and Technology, 6(16), 2976-2983. https://doi.org/10.19026/rjaset.6.3681

Kasilingam, G., \& Chinnavan, E. (2014). Assessment of learning domains to improve student' $\mathrm{s}$ learning in higher education. Journal of Young Pharmacists, 6(4), 27-33. https://doi.org/10.5530/jyp.2014.1.5

Maknun, D., Surtikanti, R. R. H. K., Munandar, A., \& Subahar, T. S. (2012). Keterampilan esensial dan kompetensi motorik laboratorium mahasiswa calon guru biologi dalam kegiatan praktikum ekologi. Journal Pendidikan IPA Indonesia, 1(2), 141-148.

Murti, S., Muhibbuddin, \& Nurmaliah, C. (2014). Penerapan Pembelajaran Berbasis Praktikum Untuk Peningkatkan Kemampuan Kognitif Dan Psikomotorik Pada Perkuliahan Anatomi Tumbuhan. Jurnal Biologi Edukasi, 6, 1-8. https://doi.org/10.1016/B978-0-08-0450933.50016-3

Osman, K., Hiong, L. C., \& Vebrianto, R. (2013). $21^{\text {st }}$ Century Biology: An Interdisciplinary Approach of Biology, Technology, Engineering and Mathematics Education. Procedia - Social and Behavioral Sciences, 102(Ifee 2012), 188-194. https://doi.org/10.1016/j.sbspro.2013.10.732

Rosa, F. O. (2015). Analisis Kemampuan Siswa Kelas X pada Ranah Kognitif, Afektif dan Psikomotorik. Jurnal Fisika Dan Pendidikan Fisika, 1(2), 24-2.

Sönmez, V. (2017). Association of Cognitive, Affective, Psychomotor and Intuitive Domains in Education, Sönmez Model. Universal Journal of Educational Research, 5(3), 347-356. https://doi.org/10.13189/ujer.2017.050307

Subekti, Y., \& Ariswan, A. (2016). Pembelajaran fisika dengan metode eksperimen untuk meningkatkan hasil belajar kognitif dan keterampilan proses sains. Jurnal Inovasi Pendidikan IPA, 2(2), 252-261. https://doi.org/http://doi.org/10.21831/jipi.v $\underline{2 \mathrm{i} 2.6278}$

Suryaningsih, Y. (2017). Pembelajaran berbasis praktikum sebagai sarana siswa untuk berlatih menerapkan keterampilan proses sains dalam materi biologi. Jurnal Bio Educatio, 2(2), 49-57.

Sutrisno, F. Z. D., Nugroho, D., \& Irawati, T. (2007). Hubungan antara kemampuan kognitif dan kemampuan psikomotorik di bidang teknologi informasi dan komunikasi di SMP Negeri 21 Surakarta. Jurnal TIkomSiN, 1-9.

Wijayanti, E., \& Mundilarto. (2015). Pengembangan Instrumen Asesmen Diri Dan Teman Sejawat Kompetensi Bidang Studi Pada Mahasiswa Developing Self-Assessment and Peer-Assessment for Students' Subject-Matter Competency. Jurnal Penelitian Dan Evaluasi Pendidikan, 19(2), 129-144. https://doi.org/10.1017/CBO9781107415324. $\underline{004}$ 